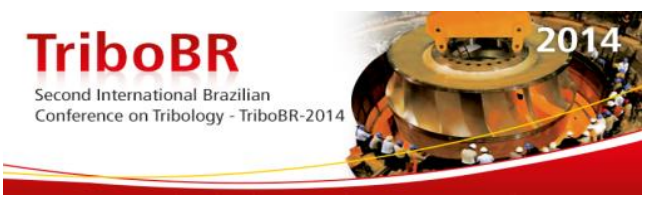

\title{
ITAIPU BINACIONAL HYDRO POWER PLANT THRUST BEARING DESIGN OPTIMIZATION FOR HIGHER EFFICIENCY*
}

\author{
Piotr Pajaczkowski ${ }^{1}$ \\ Michel Spiridon ${ }^{2}$ \\ Andreas Schubert ${ }^{3}$ \\ Geraldo Carvalho Brito Júnior ${ }^{4}$ \\ João Maria Marra ${ }^{5}$
}

\begin{abstract}
Hydro generators installed in Itaipu Binacional power plant with 824/737 MVA rated output power $(50 / 60 \mathrm{~Hz})$ belong to the largest ones in the world. Among many unique features the generators are equipped with the largest hydrodynamic thrust bearings ever built (external diameter $5200 \mathrm{~mm}$, axial load equals approximately $3600 \mathrm{t}$ ). This paper is an attempt to propose a new thrust bearing design with the use of the stateof-the-art technologies and simulation techniques that demonstrate a reduction of friction power losses generated by the thrust bearing. This paper is divided into two parts. Within the first one the original thrust bearing design which was implemented in the generators is described. Related calculation results based on a thermo-elastohydrodynamic (TEHD) calculation software used by Alstom will be presented. A comparison between measurement results gathered in the 1980's is given. In the second part a potential solution of a more beneficial bearing design is described. The proposed thrust bearing design modification is an implementation of Alstom's Polypad $^{\mathrm{TM}}$ coating. This modern polymer (PEEK) coating material has already been used by Alstom in projects around the world for many years. This coating allows pushing the operating parameters limits toward higher temperatures and lower oil film thicknesses far beyond the limits known for the conventional bearing materials.
\end{abstract}

Keywords: Hydrodynamic thrust bearings; Simulations; Measurements.

1 Dr. Eng., Development Engineer, Hydro R\&D, Alstom Renewable, Birr, Switzerland.

2 M.Sc. Eng., MBA, R\&D Manager, Mechanical Design Generator Expert, Alstom Renewable Power Hydro, Birr, Switzerland.

3 M.Sc. Eng., Principle Engineer, Alstom Renewable Power Hydro, Birr, Switzerland.

4 M.Sc. Eng., Senior Engineer, Eletromechanical Engineering Department, Itaipu Binacional, Foz do Iguacu, Brazil.

5 M.Sc. Eng., Senior Engineer, Maintenance Engineering Department, Itaipu Binacional, Foz do Iguacu, Brazil.

* Technical contribution to the $2^{\text {nd }}$ International Brazilian Conference on Tribology - TriboBR 2014, November $3^{\text {rd }}$ to $5^{\text {th }}$, 2014, Foz do Iguaçu, PR, Brazil. 


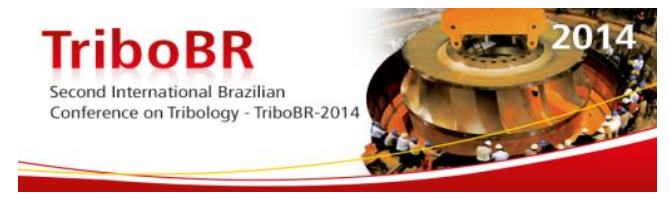

\section{INTRODUCTION}

Hydro generators installed in Itaipu Binacional power plant with 824/737 MVA rated output power $(50 / 60 \mathrm{~Hz})$ belong to the largest ones in the world. Among many unique features the generators are equipped with the largest hydrodynamic thrust bearings ever built (external diameter $5200 \mathrm{~mm}$, axial load can reach up to approximately $3600 \mathrm{t}$ ). It has been more than thirty years since these thrust bearings were designed. During this time some significant developments in bearing technologies as well as in simulation techniques have been observed. This paper is an attempt to propose a new thrust bearing design with the use of the state-of-the-art technologies and simulation techniques that demonstrate a reduction of friction power losses generated by the thrust bearing and improve efficiency of the whole generator. The general idea is to bring the bearing design closer to the limits of the operational safety but without exceeding these limits. Operational safety limits for hydrodynamic bearings are described in detail in [1]. This goal can be achieved only if the calculation methods allow to maintain satisfactory accuracy during the design phase. This study will show first of all validation of the calculation model with the use of measurement data. Afterwards a comparison of an existing design (see Figure 1) with the new bearing proposal is described. Finally the results of a heavily loaded thrust bearing under transient load are presented.
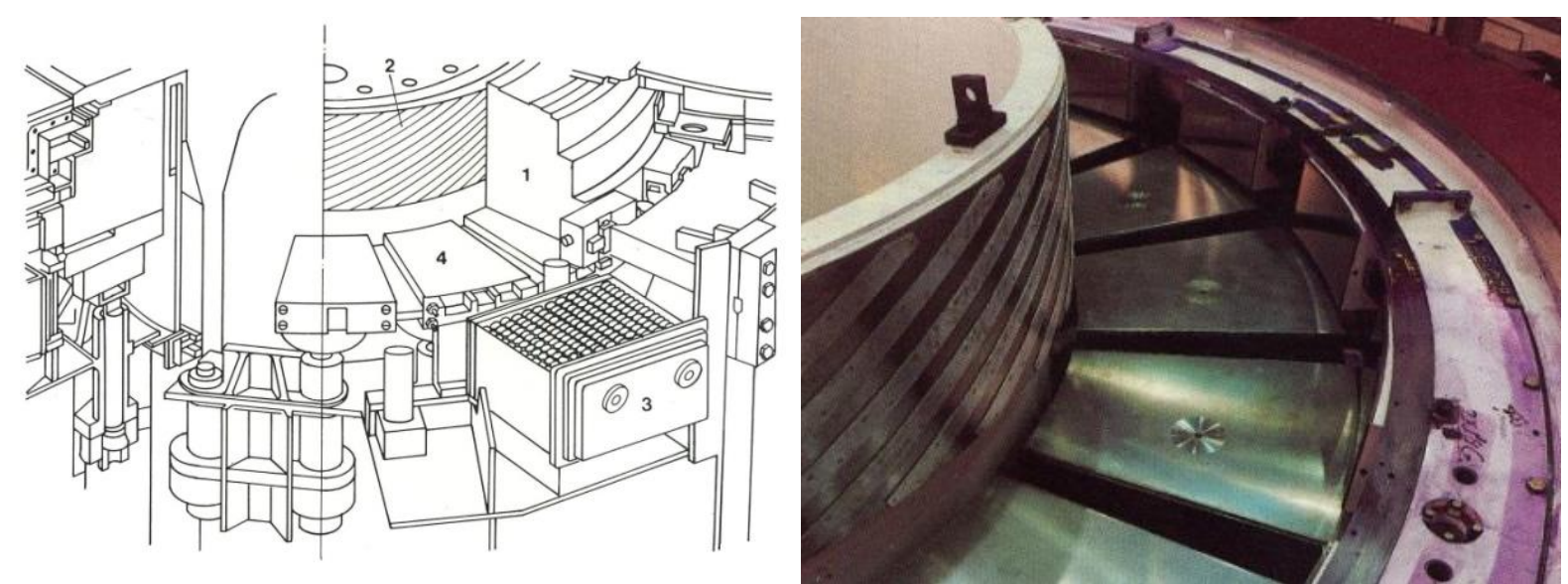

Figure 1. Thrust bearing of an Itaipu hydro generator [2] 1) thrust runner, 2) generator lower shaft, 3 ) thrust bearing oil to water heat exchanger, 4) thrust pad

\section{CALCULATION MODEL}

Related calculation results based on thermo-elasto-hydrodynamic (TEHD) calculation software, used by Alstom, are presented in this chapter. This program allows taking into account most of significant effects that occur within the bearing oil film and within the spaces between the thrust pads, like:

- three dimensional temperature and viscosity treatment,

- heat transfer between oil film and bearing components (pad coating, pad body and runner),

- laminar to turbulent oil flow transition,

- mixing effects between thrust pads,

- cavitation in divergent oil film zones,

- coupling with an external finite elements program for prediction of the thermoelastic deformations of the bearing components.

* Technical contribution to the $2^{\text {nd }}$ International Brazilian Conference on Tribology - TriboBR 2014, November $3^{\text {rd }}$ to $5^{\text {th }}$, 2014, Foz do Iguaçu, PR, Brazil. 


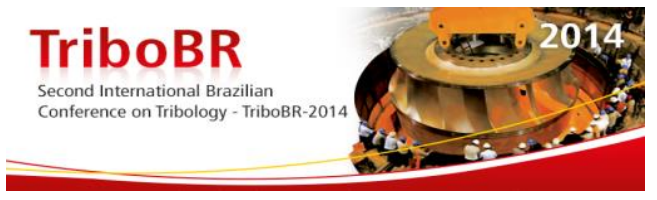

The iterative calculation process within this program is based on three iteration loops. The most internal loop (hydraulic coupling) solves hydrodynamic Reynolds equation for velocity and pressure fields. Within the second iteration loop the energy equations are solved in order to estimate heat dissipation and transfer, temperatures and finally viscosity fields (energetic coupling). Within the most outer loop the balance of the bearing elements and the tilt position of the pad are estimated (mechanical coupling). More detailed description of the calculation software can be found in [3].

Two Finite Elements (FE) models are coupled with the bearing simulation tool for estimation of the thermo-elastic pad and runner deformations. Resulting deformations are imposed in the following iteration of the bearing calculation program. The iterative process is carried on until the main operating parameters of the bearing stabilize - change between two subsequent iterations is lower than $1 \%$. An example of calculation result from FE calculation program is given in Figure 2.
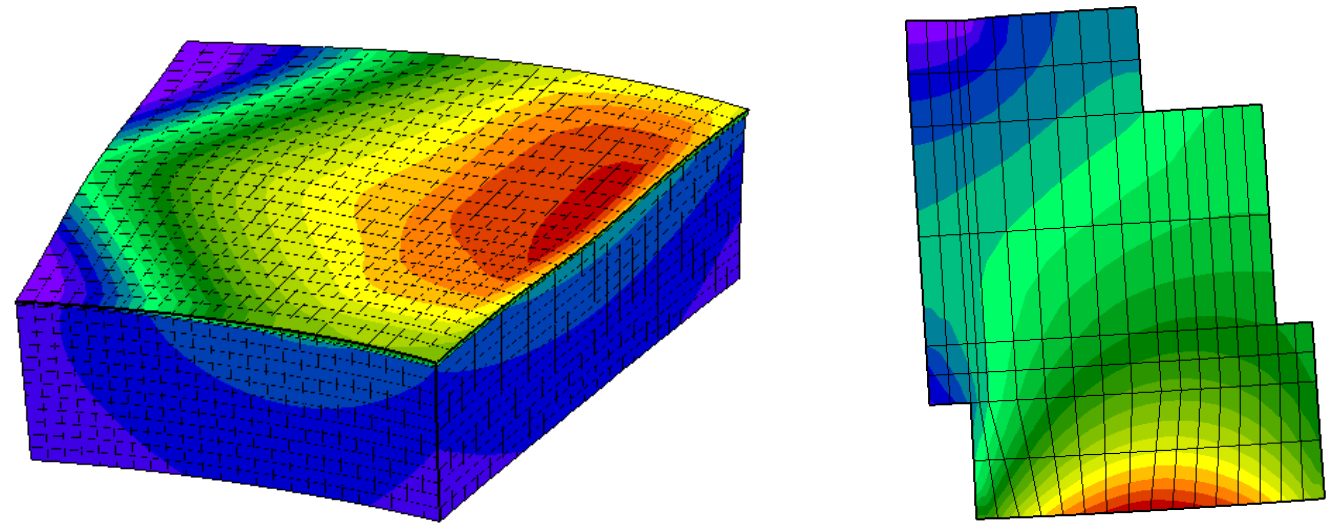

Figure 2. FE calculation results for pad and runner, temperature fields and thermo-elastic deformations.

In order to simulate bearing behaviour with the highest possible accuracy, the thermal and mechanical properties of the polymer coating material are based on the measured values which are listed in Table 1.

Table 1. Thermal and mechanical properties of Polypad ${ }^{\mathrm{TM}}$ coating material

\begin{tabular}{lcc}
\hline Parameter & Value & Unit \\
\hline Mechanical strength @ $100^{\circ} \mathrm{C}$ & 150 & {$[\mathrm{MPa}]$} \\
\hline Bonding shear strength @ $120^{\circ} \mathrm{C}$ & 28 & {$[\mathrm{MPa}]$} \\
\hline Young module & 3.5 & {$[\mathrm{GPa}]$} \\
\hline Thermal conductivity & 0.4 & {$[\mathrm{~W} / \mathrm{m} \mathrm{K}]$} \\
\hline Melting point temperature & 343 & {$\left[{ }^{\circ} \mathrm{C}\right]$} \\
\hline Dry friction coefficient & 0.1 & {$[-]$} \\
\hline
\end{tabular}

Structure of the Polypad ${ }^{\mathrm{TM}}$ coating is given in Figure 3. A layer of PEEK (Poly Ether Ether Ketone) is mechanically bonded with steal backing of the pad by the means of sintered bronze technology. Thickness of the whole composite layer equals approximately $3 \mathrm{~mm}$.

\footnotetext{
* Technical contribution to the $2^{\text {nd }}$ International Brazilian Conference on Tribology - TriboBR 2014, November $3^{\text {rd }}$ to $5^{\text {th }}$, 2014, Foz do Iguaçu, PR, Brazil.
} 

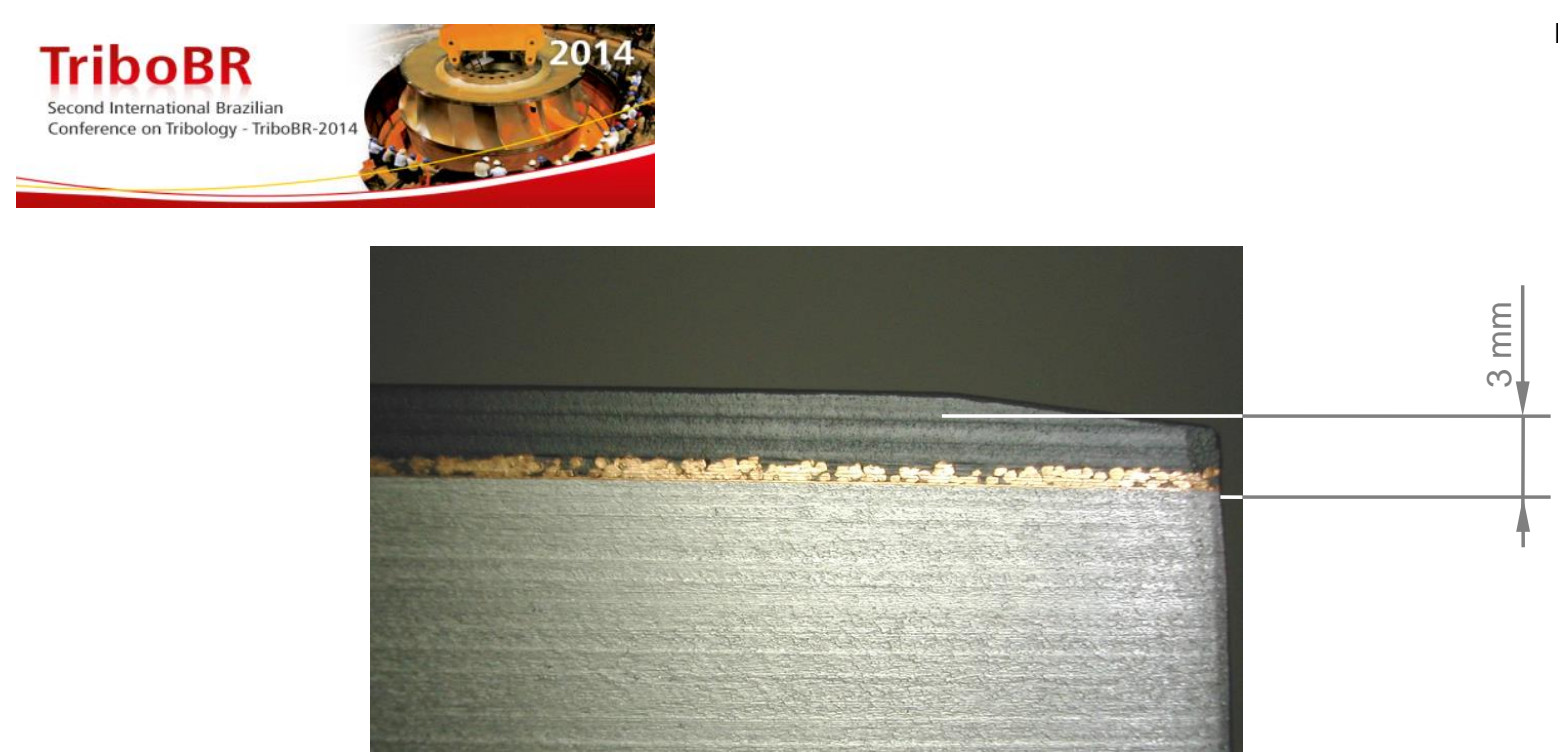

Figure 3. Polypad ${ }^{\mathrm{TM}}$ coating with sintered bronze bonding technology.

\section{MODEL VALIDATION AND CALCULATION RESULTS}

\subsection{Validation of the Model with Measurement Data}

A comparison between measurement results gathered in the 1980's for the purpose of the calculation model validation is given. Measurements performed at site allowed to collect a large number of important information about the bearing condition. All the most important bearing parameters were measured during these tests: oil film thickness and hydrodynamic pressure profiles with the use of sensors installed inside the thrust runner and several temperatures collected from the thrust runner (7 sensors) and two thrust pads (25 sensors) parts as well as within the space between the thrust pads (10 sensors).

During an extensive measurement campaign realized at site in 1980's a large amount of operational data was collected. For simplicity only the results from nominal operation point are shown. The bearing related operational parameters are summarized in Table 2, geometrical properties of the bearing are listed in Table 3. Rated load was increased by $6 \%$ in order to fit more accurately the load value that was acting on the test pad during the measurements.

Table 2. Operational parameters during measurement at rated load

\begin{tabular}{lccc}
\hline Parameter & Value & Unit \\
\hline Rotational speed & & 92 & {$[\mathrm{rpm}]$} \\
\hline Thrust load & $(27.7 \times 1.06)$ & 29.4 & {$[\mathrm{MN}]$} \\
\hline Oil grade & 54 & ISO VG \\
\hline Cold oil temperature (cooler outlet) & 40 & {$\left[{ }^{\circ} \mathrm{C}\right]$} \\
\hline Warm oil temperature (cooler inlet) & 50 & {$\left[{ }^{\circ} \mathrm{C}\right]$} \\
\hline
\end{tabular}

Comparison between measured and calculated oil film thickness profiles at average radius $(R=2112.5 \mathrm{~mm})$ are given in Figure 4 . Calculated profile indicated slightly lower oil film thickness profile. Calculated minimum oil film thickness equals $52.2 \mu \mathrm{m}$ whereas the measured value equals $67 \mu \mathrm{m}$. Calculated oil film inlet height equals $249 \mu \mathrm{m}$ compared to measured $358 \mu \mathrm{m}$. Outlet to inlet height ratios 4.77 (calculated) and 5.34 (measured) indicate that the hydrodynamic behaviour of the pad is estimated much closer than could be the absolute values of the oil film gap.

* Technical contribution to the $2^{\text {nd }}$ International Brazilian Conference on Tribology - TriboBR 2014, November $3^{\text {rd }}$ to $5^{\text {th }}$, 2014, Foz do Iguaçu, PR, Brazil. 

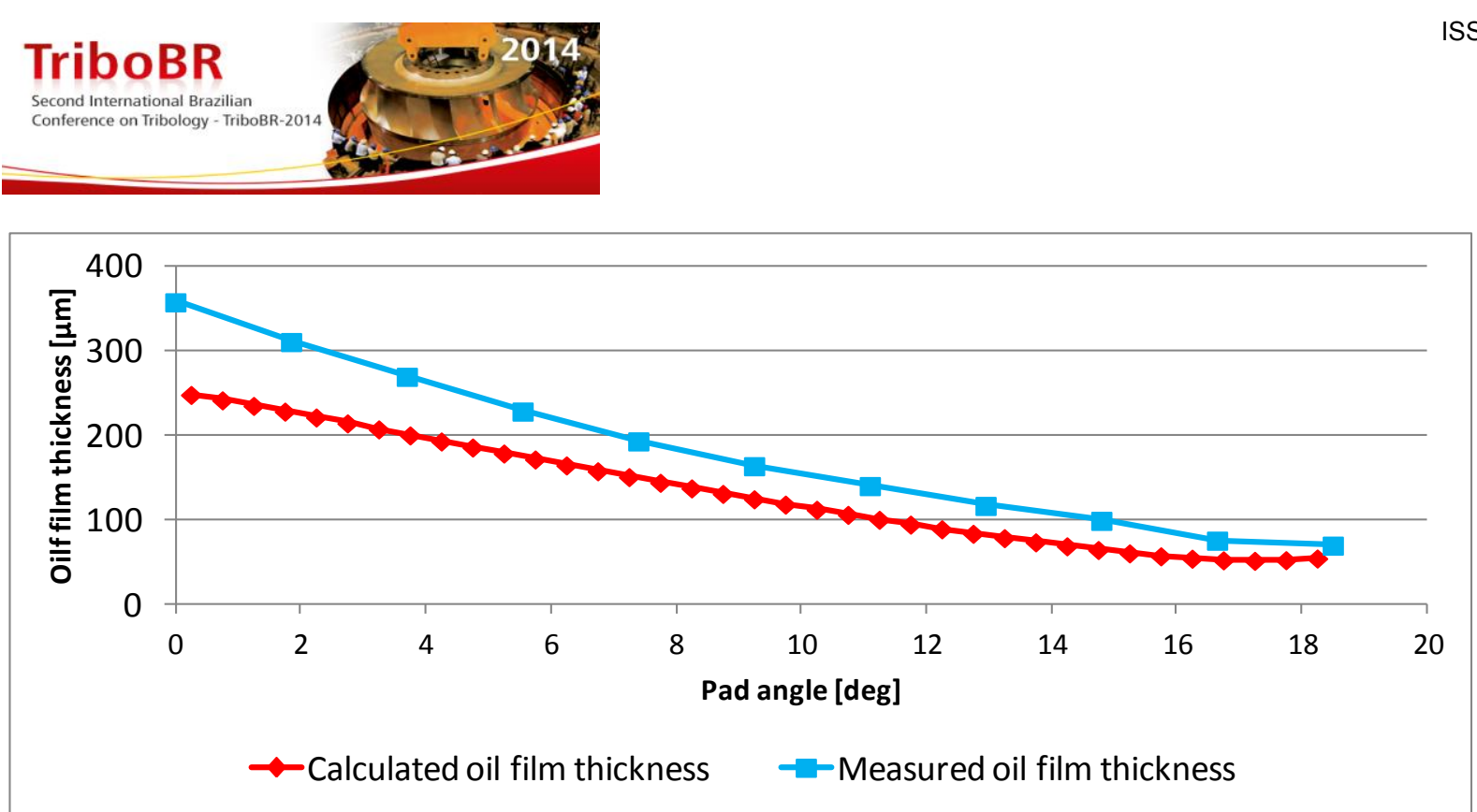

Figure 4. Comparison of the measured and calculated oil film thickness profiles on the average radius $R=2112.5 \mathrm{~mm}$.

Original technical drawing from 1981 with temperature sensors positions is presented in Figure 5.

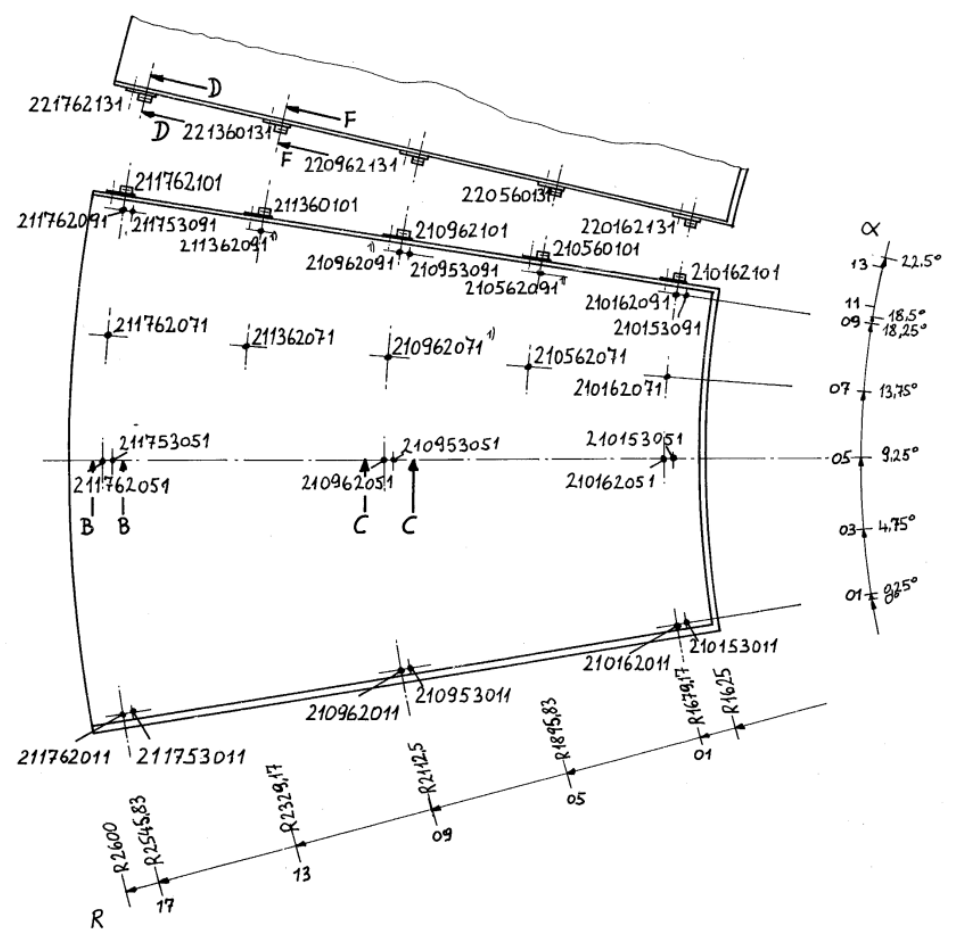

Figure 5. Distribution of the temperature sensors on the pad surface

Measured and calculated temperature profiles are presented in Figure 6. Generally quite good agreement has been achieved. The calculated temperature profiles on the inner $(R=1679.2 \mathrm{~mm})$ and outer $(R=2545.8 \mathrm{~mm})$ pad edges fit almost exactly to the measured ones. Calculated temperatures on the average radius ( $R=2112.5 \mathrm{~mm}$ ) are lower than the measured ones. Temperatures values are in a very good agreement on the leading and trailing edges.

* Technical contribution to the $2^{\text {nd }}$ International Brazilian Conference on Tribology - TriboBR 2014, November $3^{\text {rd }}$ to $5^{\text {th }}$, 2014, Foz do Iguaçu, PR, Brazil. 


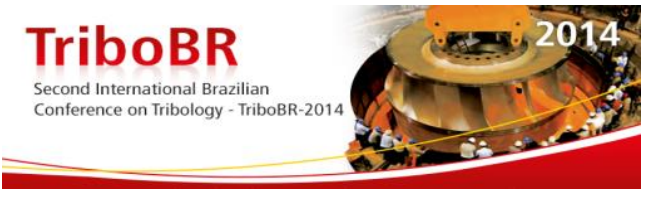

\subsection{New Thrust Bearing Design Proposal}

Since the thrust bearings for Itaipu generators were designed with the use of materials and technology available in 1970's their configuration has still significant optimisation potential. In this chapter a proposal of a more beneficial bearing design is described. The goal of the optimization is to limit the power losses (efficiency improvement) resulting from the bearing dimensions reduction and an increase of the bearing specific load. It is not the aim of this article to perform a comprehensive redesign of the current Itaipu bracket and respective detailed modifications needed to accommodate the new bearing dimensions, otherwise to show the potential of latest bearing technology available in large machines. The proposed thrust bearing design modification is an implementation of Alstom's Polypad ${ }^{\mathrm{TM}}$ coating. This modern PEEK polymer coating material has already been used by Alstom in projects around the world for many years. This coating allows pushing the operating parameters limits toward higher temperatures and lower oil film thicknesses far beyond the limits known for the conventional bearing materials. Due to its thermal and mechanical strengths as well as high wear resistance, the bearings can be downsized and loaded with significantly higher loads. This brings significant efficiency improvements. Due to low thermal conductivity of the Polypad ${ }^{\mathrm{TM}}$ coating, the bearing pads have less thermal deformations compared to conventional materials, what additionally increases the load carrying capacity of the thrust bearing.

Due to need of compatibility with the existing shafts and brackets the inner bearing diameter remained unchanged. Since the width of the pads had to be significantly reduced, in order to maintain value of the length to width ratio less than 1, it was necessary to increase number of the pads from 16 to 24. Existing bearing bracket has 8 supporting arms so with 24 thrust pads it is still possible to maintain integer number of pads per arm. Covered surface factor (pads area / total ring area) increased from $82.2 \%$ for the existing design to $86.6 \%$ for the new one. The main dimensions of both thrust bearings are compared in Figure 8 and Table 3.
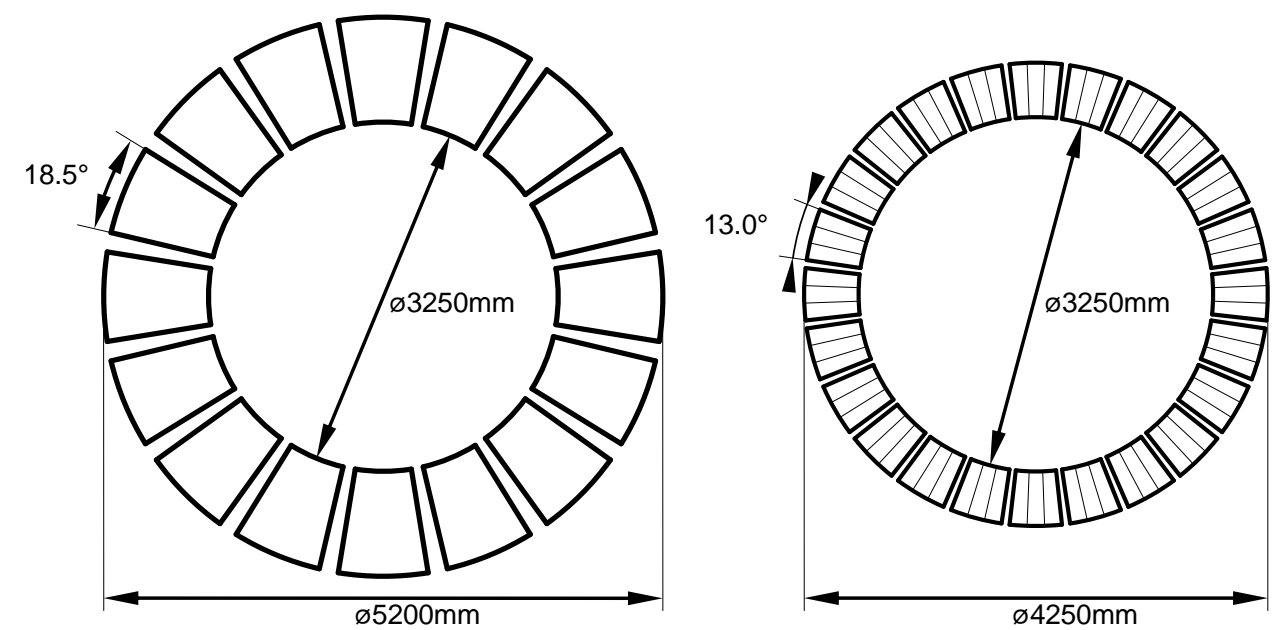

Figure 8. Comparison of the bearing designs, left: old bearing, right: new bearing with polymer coating and tapered sliding surface

High loaded bearings tend to operate with lower oil film inlet / outlet height ratio which leads to increased oil film inlet temperatures. In order to improve this parameter new bearing makes use of the oil film inlet / outlet taper design feature. The authors carefully investigated this modification of the sliding surface. It has been described in detail in $[5,6]$ and already successfully implemented in several hydro generator

* Technical contribution to the $2^{\text {nd }}$ International Brazilian Conference on Tribology - TriboBR 2014, November $3^{\text {rd }}$ to $5^{\text {th }}$, 2014, Foz do Iguaçu, PR, Brazil. 
thrust bearings. The main goal of this modification is to increase artificially the pad crowning in circumferential direction and to let more fresh oil to enter the oil film. In general it enables bidirectional and/or polymer coated and/or heavily loaded bearings to operate at lower temperatures.

Table 3. Comparison of the main properties of the thrust bearings

\begin{tabular}{lccc}
\hline Parameter & Existing & Proposed & Unit \\
\hline Outer diameter & 5200 & 4250 & {$[\mathrm{~mm}]$} \\
\hline Inner diameter & 3250 & 3250 & {$[\mathrm{~mm}]$} \\
\hline Pad thickness & 230 & 150 & {$[\mathrm{~mm}]$} \\
\hline Number of pads & 16 & 24 & {$[-]$} \\
\hline Pad angle & 18.5 & 13 & {$[\mathrm{deg}]$} \\
\hline Support position in tangential direction & 0.60 & 0.60 & {$[-]$} \\
\hline Support position in radial direction & 0.50 & 0.50 & {$[-]$} \\
\hline Coating material & Babbitt & Polypad & {$[-]$} \\
\hline Taper design & w/o taper & w/ taper & {$[-]$} \\
\hline Rated specific pressure $(29.4 \mathrm{MN})$ & 2.76 & 5.76 & {$[\mathrm{MPa}]$} \\
\hline Transient specific pressure $(36.0 \mathrm{MN})$ & 3.38 & 7.05 & {$[\mathrm{MPa}]$} \\
\hline
\end{tabular}

Comparison of the main calculation results of the both thrust bearing designs is given in Table 4. During design of the modified bearing an optimization process has been carried out in order to identify the most favourable profile (taper depth and length) of the sliding surface.

Table 4. Comparison of the main operating parameters at rated load

\begin{tabular}{lccc}
\hline Parameter & Existing & Proposed & Unit \\
\hline Minimum oil film thickness & 52.2 & 26.9 & {$[\mu \mathrm{m}]$} \\
\hline Maximum oil film temperature & 84.9 & 94.5 & {$\left[{ }^{\circ} \mathrm{C}\right]$} \\
\hline Pad temperature at $0.5 \mathrm{R} / 0.75 \mathrm{~L} / 6 \mathrm{~mm}$ & 75 & 59 & {$\left[{ }^{\circ} \mathrm{C}\right]$} \\
\hline Maximum runner deformation & 58.1 & 42.0 & {$[\mu \mathrm{m}]$} \\
\hline Maximum runner temperature & 69.5 & 81.1 & {$\left[{ }^{\circ} \mathrm{C}\right]$} \\
\hline Maximum oil film pressure & 10.7 & 17.3 & {$[\mathrm{MPa}]$} \\
\hline Maximum / specific pressure ratio & 3.9 & 3.0 & {$[-]$} \\
\hline Power losses of the thrust bearing & 572.8 & 325.3 & {$[\mathrm{~kW}]$} \\
\hline Power losses of the guide bearing & 319.7 & 176.8 & {$[\mathrm{~kW}]$} \\
\hline Total power losses & 892.5 & 502.1 & {$[\mathrm{~kW}]$} \\
\hline Required cooling oil flow for $\Delta \mathrm{T}=10^{\circ} \mathrm{C}$ & 3157 & 1776 & {$[\mathrm{~L} / \mathrm{min}]$} \\
\hline Required minimum oil tank capacity & 12628 & 7104 & {$\left[\mathrm{dm}{ }^{3}\right]$} \\
\hline
\end{tabular}

Due to smaller size of the polymer coated bearing it was possible to reduce its power losses by $43.2 \%$ from 572 to $325 \mathrm{~kW}$. Estimated power loss savings for the guide bearing are also high - reduction from 319.7 to $176.8 \mathrm{~kW}$. Consequently total power loss of the combined thrust guide bearing decreased by $43.7 \%$ from 892.5 to $502.1 \mathrm{~kW}$. This significant total power loss reduction could potentially lead to

* Technical contribution to the $2^{\text {nd }}$ International Brazilian Conference on Tribology - TriboBR 2014, November $3^{\text {rd }}$ to $5^{\text {th }}$, 2014, Foz do Iguaçu, PR, Brazil. 


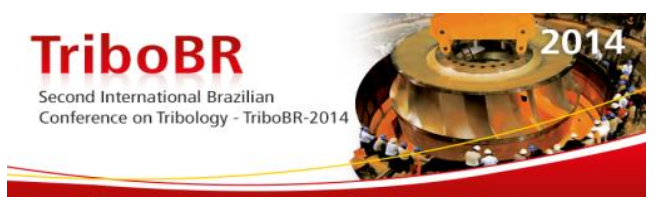

of all elastic deformations of the polymer lining are significantly higher than these for babbitted pads. The Young modulus for PolypadTM is more than one order of magnitude lower than for Babbitt. At the same time the pad thermal deformations are significantly reduced in case of polymer coated thrust bearing due to insulating properties of the lining material.

Even though the thrust bearing operates at slightly higher temperature, thanks to reduced width of the bearing, the thermal crowning of the thrust runner is lower in case of the polymer coated bearing. Similar like in case of the pad deformations this effect contributes to load carrying capacity improvement. The resulting deformations of the sliding surfaces are shown in Figure 11.
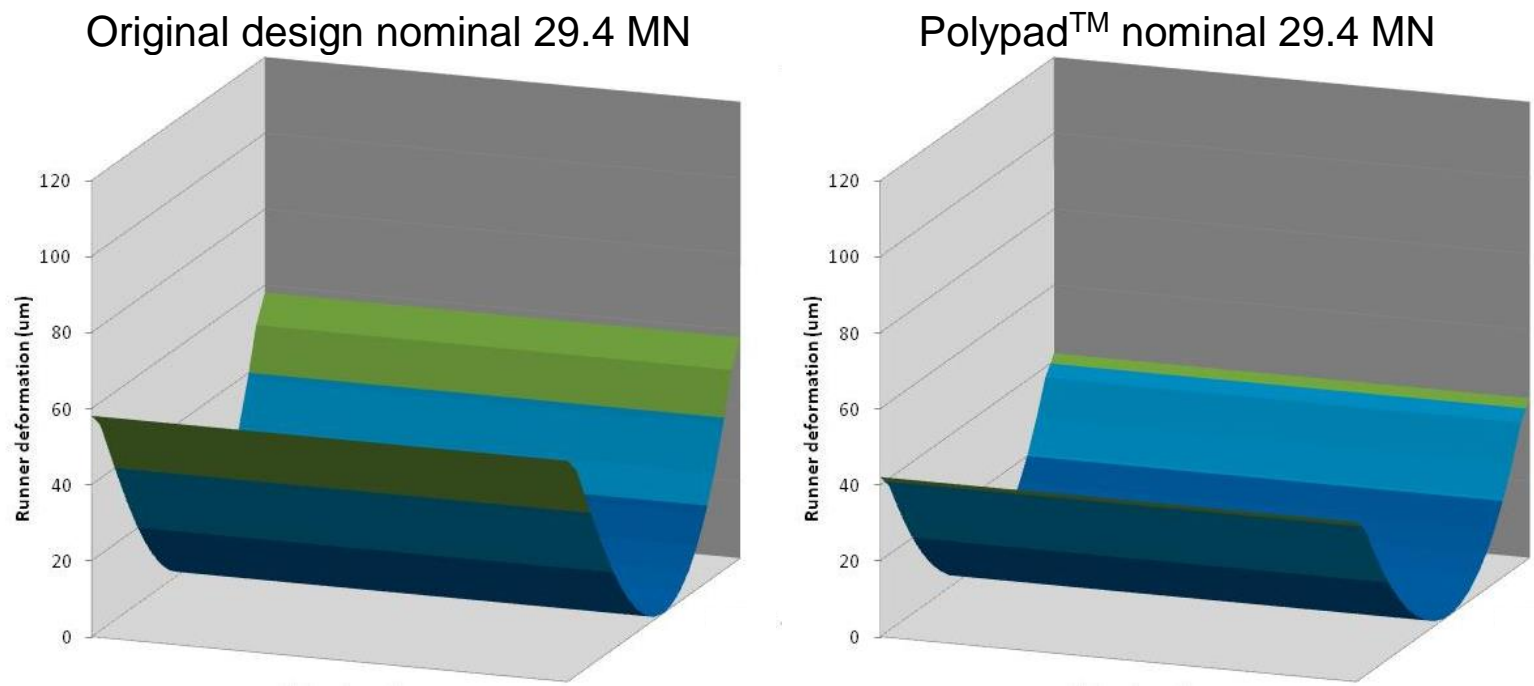

Figure 11. Comparison of the thrust runner deformations

Hydrodynamic pressure fields are compared in Figure 12.
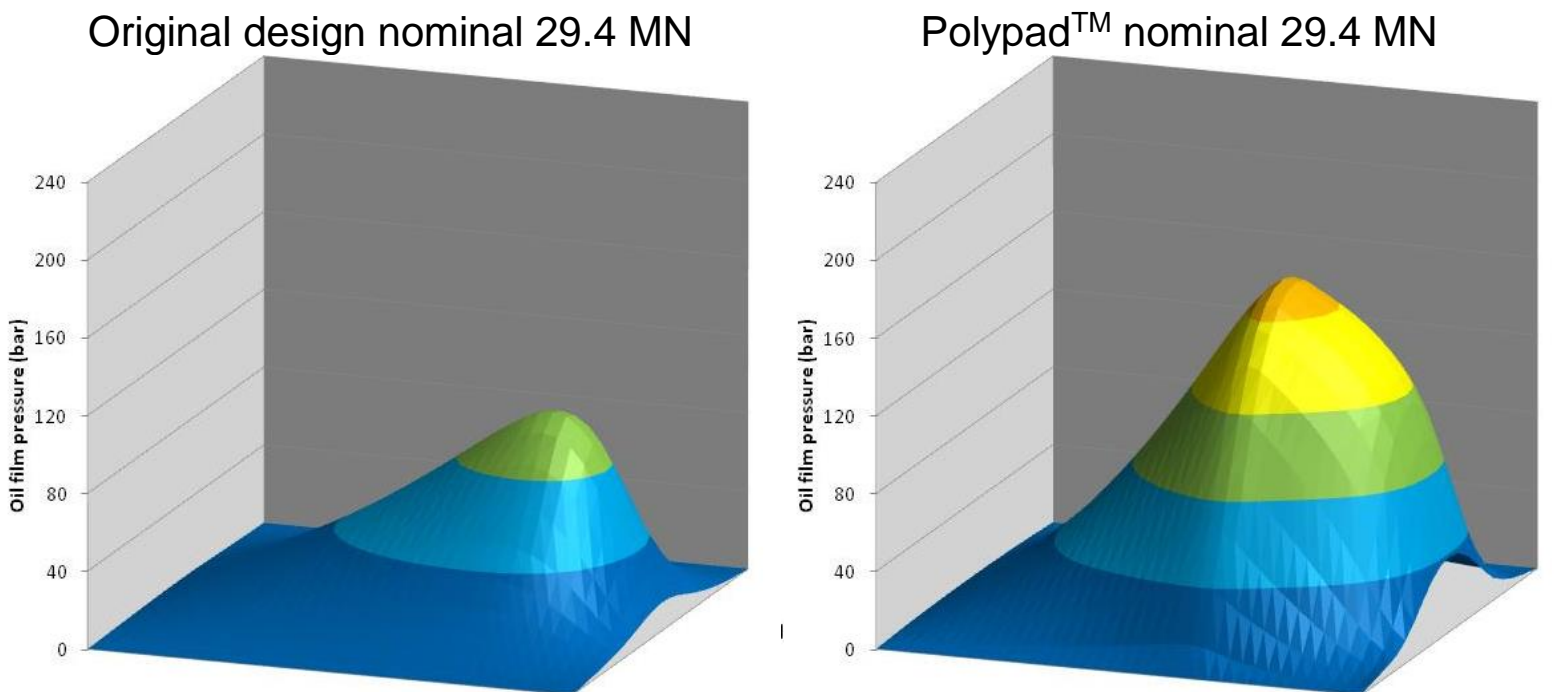

Figure 12. Comparison of the hydrodynamic pressure fields.

Maximum value is significantly higher in case of the polymer coated pad due to higher specific load but the ratio between maximum and average value is lower (3.9 and 3.0 respectively). This indicates more uniform pressure distribution in the oil film. One can also observe this effect in Figure 12, where the pressure profile of a polymer coated pad looks more "filled". This behavior has two reasons. First of all pad and

* Technical contribution to the $2^{\text {nd }}$ International Brazilian Conference on Tribology - TriboBR 2014, November $3^{\text {rd }}$ to $5^{\text {th }}$, 2014, Foz do Iguaçu, PR, Brazil. 


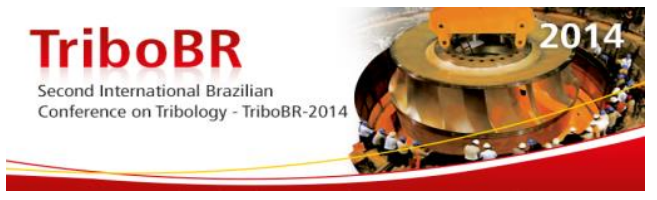

runner deformations in radial direction are significantly lower. Additionally a "pocket" shape of pad surface decreases side leakages from the oil film. Due to optimized tapered design there is no divergent zone in the outlet region, which could potentially cause significant reduction of the pad surface.

Temperature fields on the cross section through the oil film, the pad and the runner are given in Figure 13. Even though the modified bearing reaches $10{ }^{\circ} \mathrm{C}$ higher temperature than the original design the maximum value of $94.5{ }^{\circ} \mathrm{C}$ is well below limits defined even for conventional bearings, which are usually set above $100{ }^{\circ} \mathrm{C}$.

Original design nominal 29.4 MN

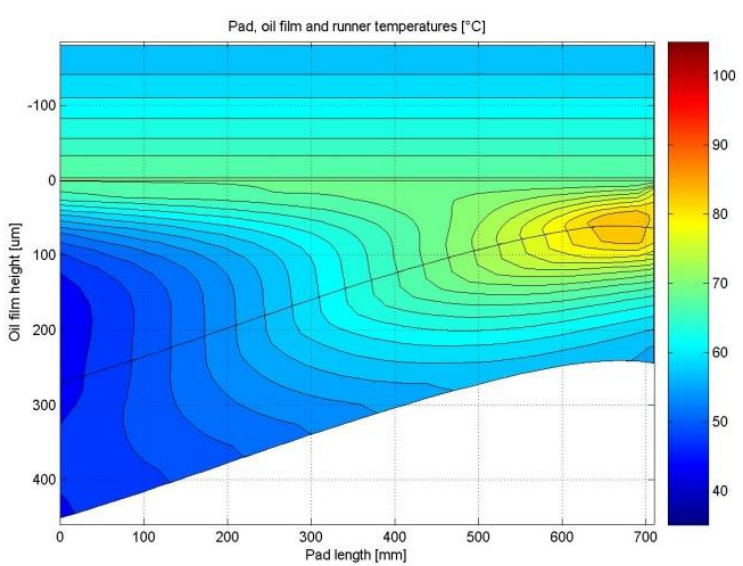

Polypad $^{\mathrm{TM}}$ nominal 29.4 MN

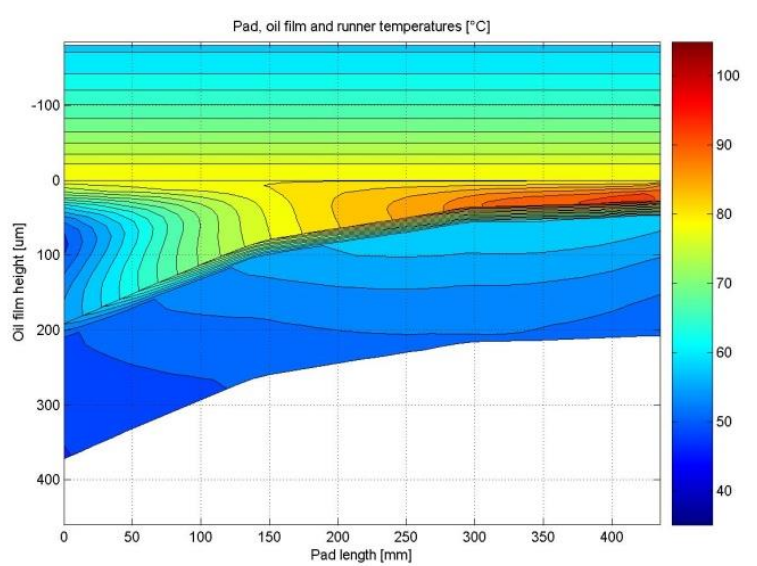

Figure 13. Temperature fields on the cross section through the bearings for average radius $(R=$ $2112.5 \mathrm{~mm}$ )

In this figure one can observe several interesting features of the calculation model. First of all three dimensional temperature fields within the oil film indicate strong temperature gradients through the oil film thickness - especially within the oil film outlet zone. The temperature contours are almost perpendicular to the pad sliding surface indicating small heat transfer rate through the pad. The steel backing of the polymer coated pad has significantly lower temperature than the babbitted one.

Original design nominal $29.4 \mathrm{MN}$

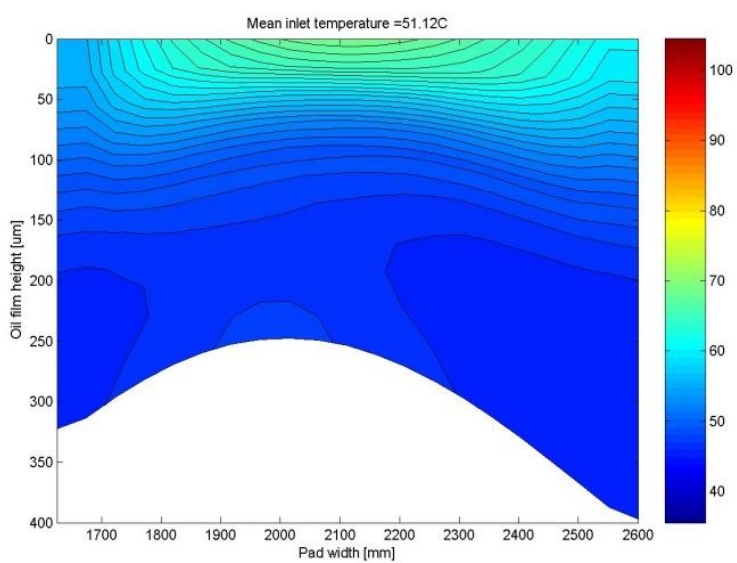

Polypad $^{\mathrm{TM}}$ nominal $29.4 \mathrm{MN}$

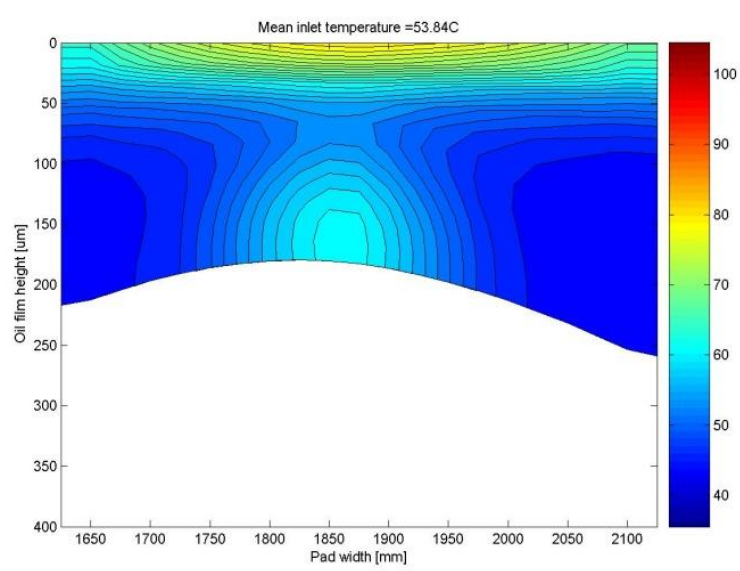

Figure 14. Oil film inlet temperature fields

Due to insulating properties of the polymer coating the pad thermal deformations are significantly reduced. Additionally, it is clearly visible that the thermal boundary layer between the pads, called warm oil mixing, is also resolved and the oil film inlet temperature is resulting from this calculation. This feature can be even better seen

* Technical contribution to the $2^{\text {nd }}$ International Brazilian Conference on Tribology - TriboBR 2014, November $3^{\text {rd }}$ to $5^{\text {th }}$, 2014, Foz do Iguaçu, PR, Brazil. 


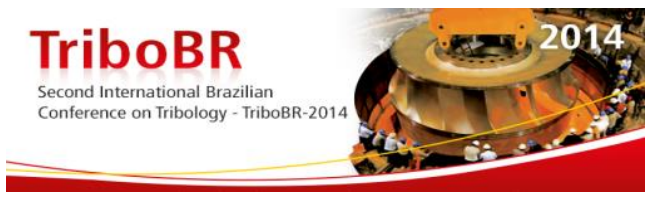

on the oil film inlet (Figure 14) and outlet (Figure 15) temperature fields and oil film thickness profiles. Oil film inlet and outlet windows of a polymer coated bearing demonstrate significantly more parallel gap profile compared to the conventional bearing. This reduction of divergence in radial direction reduces side leakages and contributes for higher load carrying capacity.

Original design nominal 29.4 MN

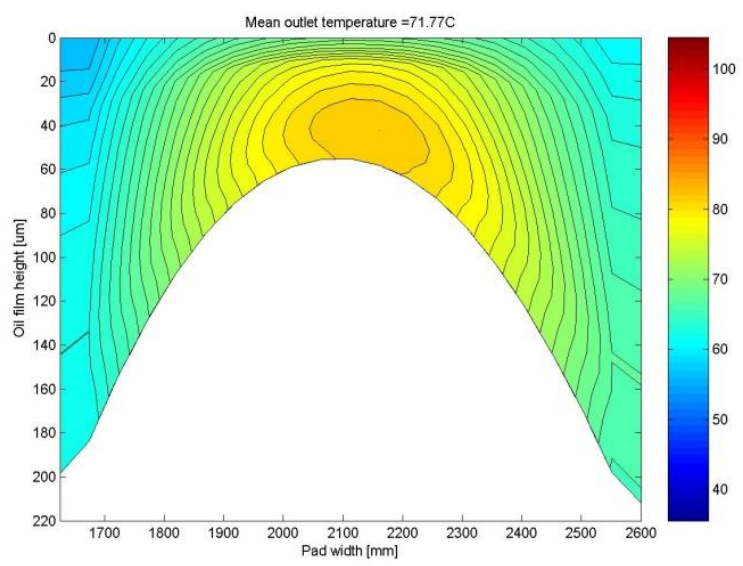

Polypad $^{\mathrm{TM}}$ nominal 29.4 MN

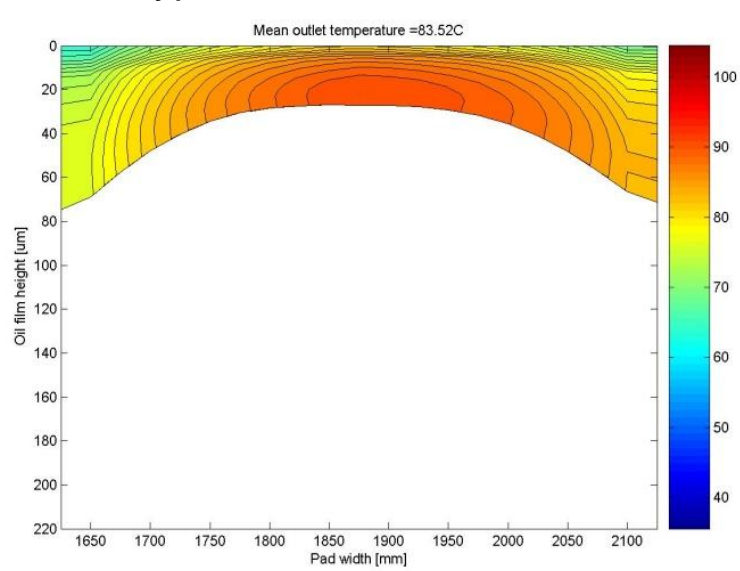

Figure 15. Oil film outlet temperature fields

\subsection{Calculation of the New Thrust Bearing under Transient Load of $36 \mathrm{MN}$}

Thrust bearing of a hydro generator has to be designed not only for the rated conditions but also for all fault cases that can occur during its lifetime. Commonly during transient periods of operation (e.g. load rejection or runaway) thrust load is significantly higher than in rated condition. In this chapter transient thrust load was assumed to equal $36 \mathrm{MN}$. This value is within the range of the maximum values expected in the Itaipu hydro generator. In this chapter two calculations of the proposed new bearing design are compared - rated and transient condition. All parameters except the load remained unchanged. Main resulting operational parameters are listed in Table 5.

Table 5. Comparison of the main operating parameters at rated and transient load

\begin{tabular}{lccc}
\hline Parameter & Rated & Transient & Unit \\
\hline Minimum oil film thickness & 26.9 & 21.5 & {$[\mu \mathrm{m}]$} \\
\hline Maximum oil film temperature & 94.5 & 99.0 & {$\left[{ }^{\circ} \mathrm{C}\right]$} \\
\hline Pad temperature at $0.5 \mathrm{R} / 0.75 \mathrm{~L} / 6 \mathrm{~mm}$ & 59 & 61 & {$\left[{ }^{\circ} \mathrm{C}\right]$} \\
\hline Maximum runner deformation & 42.0 & 49.4 & {$[\mu \mathrm{m}]$} \\
\hline Maximum runner temperature & 81.1 & 87.1 & {$\left[{ }^{\circ} \mathrm{C}\right]$} \\
\hline Maximum oil film pressure & 17.3 & 22.9 & {$[\mathrm{MPa}]$} \\
\hline Maximum / specific pressure ratio & 3.0 & 3.2 & {$[-]$} \\
\hline Power losses of the thrust bearing & 325.3 & 339.4 & {$[\mathrm{~kW}]$} \\
\hline
\end{tabular}

The most interesting results of the transient bearing operation are given in Figures 16,17,18 and 19. The thrust bearing behaviour under high load (specific pressure higher than $7 \mathrm{MPa}$ ) is in general similar to the rated condition. Minimum oil film thickens reduced from 27 to $21 \mu \mathrm{m}$ but remained still within the safe region above 20

* Technical contribution to the $2^{\text {nd }}$ International Brazilian Conference on Tribology - TriboBR 2014, November $3^{\text {rd }}$ to $5^{\text {th }}$, 2014, Foz do Iguaçu, PR, Brazil. 


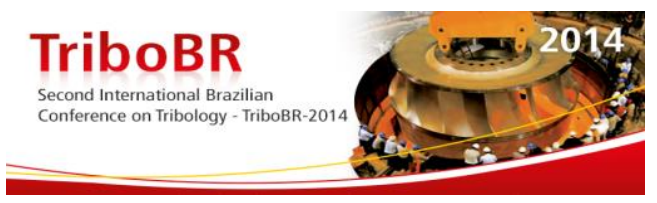

$\mu \mathrm{m}$. Maximum oil film temperature increased from 94.4 to $99.0{ }^{\circ} \mathrm{C}$ which is still very safe value from the bearing coating as well as from the oil durability point of view. Maximum to specific pressure ratio increased from 3.0 to 3.2 indicating higher impact of the runner increased thermal crowning. Power losses increased slightly from 325.3 to $339.4 \mathrm{~kW}$ due to higher shear stresses in the thinner oil film.
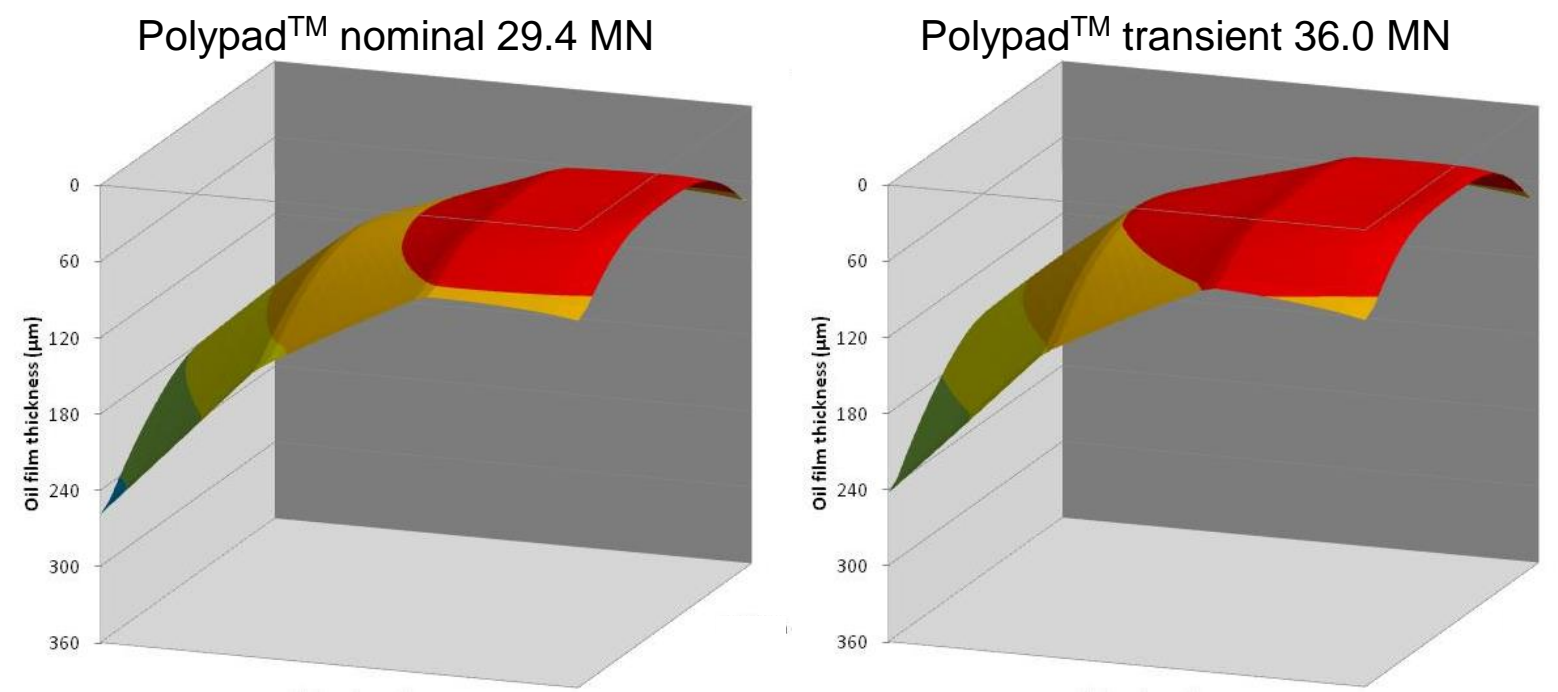

Figure 16. Comparison of the oil film thickness geometries

Thermo-elastic deformations of the polymer coated surface indicate slightly higher which leads to even better compensation of the thrust runner thermal crowning.
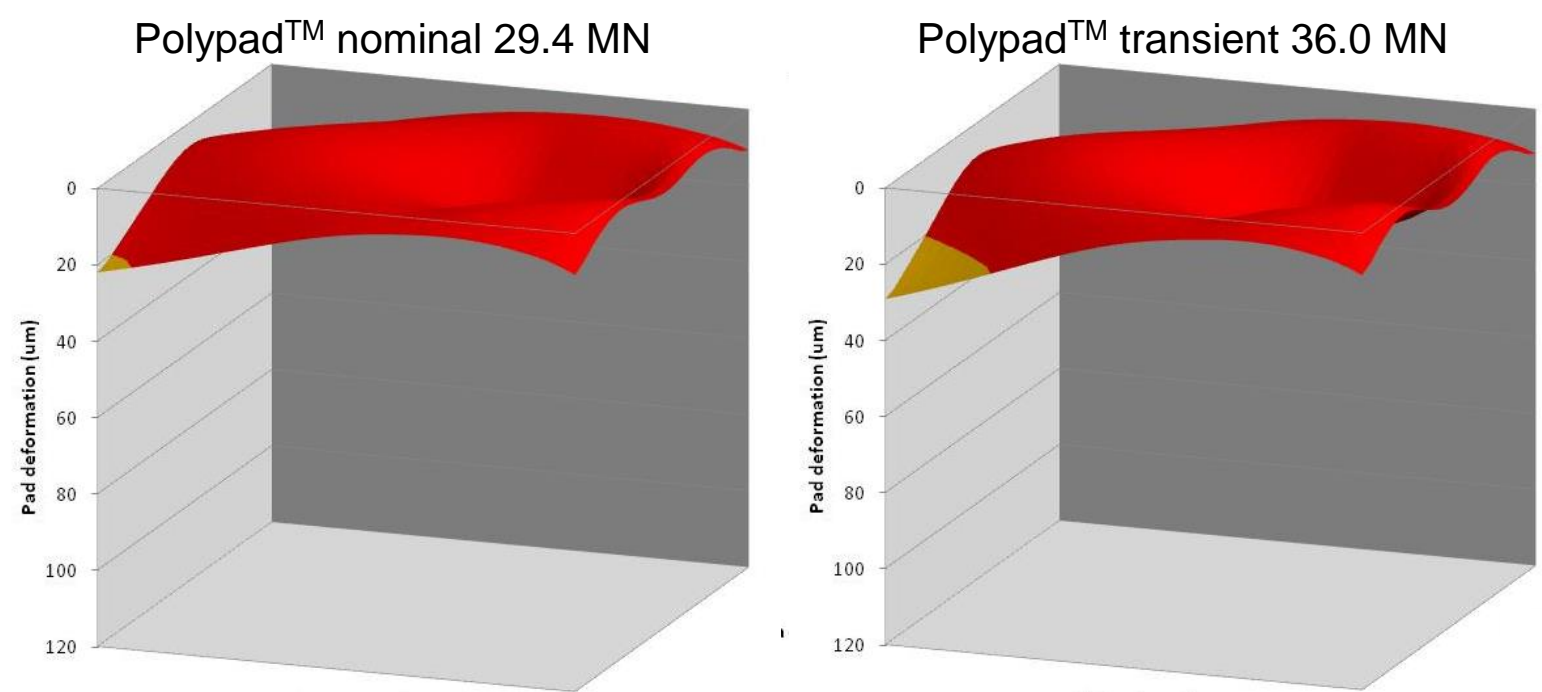

Figure 17. Comparison of the thrust pad deformations

Maximum pressure values increased compared to rated condition but the pressure field remained very similar. It still shows very clearly a filled profile in the oil film outlet zone. This indicated one of the main advantages of the polymer lined bearings - self adaptation. Due to high elasticity of the coating there is no divergent oil film region and consequently the pad area is utilized in optimal way. It results finally in uniform pressure distribution and high load carrying capacity of the whole bearing.

* Technical contribution to the $2^{\text {nd }}$ International Brazilian Conference on Tribology - TriboBR 2014, November $3^{\text {rd }}$ to $5^{\text {th }}$, 2014, Foz do Iguaçu, PR, Brazil. 
execution as well as power loss savings during whole operational lifetime justify implementation of such bearing technology.

\section{REFERENCES}

1 Leopard AJ. Tilting Pad Bearings - Limits of Operation, Lubrication Engineering, 1976; 32(12): 637-644.

2 Cotrim JR, Itaipu (Power plant), Itaipu hydroelectric Project. Engineering Features. Itaipu Binacional, Curitiba, Brazil 1994.

3 Kraft C, Schwarze H, Verbesserte Axialgleitlagerberechnung. Hochbelastete, schnelllaufende Axialgleitlager in einfacher und doppeltwirkender Anordnung unter Berücksichtigung statischer Spurscheibenverkantung. FVV-Vorhaben Nr. 1002, Abschlussbericht, Clausthal 2012.

4 Wodtke M, Schubert A, Fillon M, Wasilczuk M and Pajaczkowski P, Large hydrodynamic thrust bearing - comparison of the calculations and measurements., Journal of Engineering Tribology, Part J, 2014: 1-10.

5 Pajaczkowski $P$, Schubert A, Brescianini T. Centrally pivoted tilting pad thrust bearing with inlet and outlet tapers - measurements vs. TEHD investigations. Poitiers: 9th EDF/Pprime (LMS) Workshop, 2010. Poitiers 2010.

6 Pajaczkowski $P$, Schubert A, Implementation of the tapered tilting pad thrust bearing design in a high speed PSP hydro generator. Poitiers: 12th EDF/Pprime (LMS) Workshop, 2013. Poitiers 2013.

* Technical contribution to the $2^{\text {nd }}$ International Brazilian Conference on Tribology - TriboBR 2014, November $3^{\text {rd }}$ to $5^{\text {th }}$, 2014, Foz do Iguaçu, PR, Brazil. 